DOI: https://doi.org/10.24127/ajpm.v9i4.3084

\title{
PENGEMBANGAN BUKU DIGITAL PADA MATERI PERSAMAAN GARIS SINGGUNG LINGKARAN
}

\author{
Linda Rosmery Tambunan ${ }^{1 *}$, Elvira Sundari ${ }^{2}$ \\ ${ }^{1 *, 2}$ Universitas Maritim Raja Ali Haji, Tanjungpinang, Indonesia \\ ${ }^{*}$ Corresponding author. \\ E-mail: $\quad$ linda_rosmery@umrah.ac.id ${ }^{1 *}$ \\ elvirasundari0808@gmail.com $^{2)}$
}

Received 03 September 2020; Received in revised form 27 December 2020; Accepted 29 December 2020

\begin{abstract}
Abstrak
Perkembangan teknologi semakin canggih dengan bukti adanya perkembangan era revolusi industri 4.0. Perkembangan ini berpengaruh pada bidang pendidikan, yang mana pembelajaran menuntut memanfaatkan alat teknologi, sesuai dengan kurikulum 2013. Tujuan penelitian ini adalah mengembangkan buku digital pada materi persamaan garis singgung lingkaran kelas XI SMA yang valid. Penelitian ini adalah penelitian pengembangan dengan model ADDIE. Teknik pengumpulan data yang digunakan adalah angket. Instrumen penelitian yang digunakan adalah lembar validasi. Data dianalisis dengan statistika deskriptif untuk mencari persentase skor rata-rata dengan bantuam msi. Hasil yang diperoleh adalah buku digital memenuhi kategori yang valid dari aspek materi dan aspek media dengan hasil persentase $64,7 \%$. Jadi, buku digital pada materi persamaan garis singgung lingkaran kelas XI SMA yang dikembangkan dinyatakan valid.
\end{abstract}

Kata kunci: buku digital; pengembangan; persamaan garis singgung lingkaran; valid

\begin{abstract}
The development of technology is increasingly sophisticated with evidence of the development of the industrial revolution era 4.0. This development has an effect on the field of education, where learning requires the use of technological tools, in accordance with the 2013 curriculum. The purpose of this study is to develop a digital book on the material tangent to circle class XI SMA which is valid. This research is a development research with the ADDIE model. The data collection technique used was a questionnaire. The research instrument used was a validation sheet. Data were analyzed using descriptive statistics to find the average score percentage with msi assistance. The results obtained are digital books that meet valid categories in terms of material aspects and media aspects with a percentage of $64.7 \%$. So, the digital book on the material for the tangent equations to circle class XI SMA that was developed is declared valid.
\end{abstract}

Keywords: development; digital book; equation tangen to circle; valid

This is an open access article under the Creative Commons Attribution 4.0 International License

\section{PENDAHULUAN}

Pada era revolusi industri 4.0 , perkembangan alat teknologi semakin modern dan berkembang dengan pesat. Dengan demikian, penggunaan alat teknologi sudah merata digunakan pada khalayak umum. Alat teknologi yang paling banyak digunakan adalah android. Android memberi kemudahan diberbagai aktifitas, mendapatkan, mencari, dan menyampaikan informasi.

Pemanfaatan alat teknologi berpengaruh pada semua bidang, terutama bidang pendidikan. Teknologi sangat bermanfaat dalam dunia pendidikan. Dengan adanya alat teknologi, peserta didik maupun pendidik dapat melakukan pencarian 
sumber-sumber belajar sebagai bahan bacaan untuk menambah wawasan dalam pembelajaran (Putri, 2018). Selain itu, pendidikan sudah menetapkan kurikulum 2013, yang mana pendidik dan peserta didik dituntut untuk belajar menggunakan alat teknologi. Tetapi praktiknya, pendidik selalu sebagai sumber utama dalam pembelajaran, sehingga peserta didik tidak berinisiatif untuk mencari sumber belajar lainnya dikarenakan peserta didik terbiasa menunggu materi dari pendidik (Cholik, 2017).

Untuk mengatasi permasalahan yang dipaparkan, maka pendidik harus melakukan sebuah inovasi dalam pembelajaran. Salah satu upaya yang dapat dilakukan adalah menggunakan buku digital. Menurut Prasetya, Widiyaningtyas, \& Prastuti (2016), buku digital adalah sebuah buku ditampilkan berbentuk digital memberikan tampilan yang lebih menarik dikarenakan dapat menyajikan teks, gambar, suara, animasi, dan video. Selain itu, kecanggihan teknologi yang semakin modern mengakibatkan kebiasaan membaca seseorang berubah, yang dulunya membawa buku kemanamana sekarang bisa membaca secara digital melalui buku digital (Wirasasmita \& Uska, 2017).

Menurut Jamun (2018), dengan adanya buku digital ini adalah salah satu media komunikasi antara pendidik dan peserta didik. Oleh karena itu, pendidik tidak hanya mengajar secara tatap muka saja, tetapi juga bisa dilakukan dengan cara jarak jauh. Seperti saat ini, yang mana proses pembelajaran dilakukan secara online dengan diawasi oleh orang tua dirumah mereka masing-masing.

Persamaan garis singgung lingkaran tepat untuk dijadikan sebuah buku digital, dikarenakan materi yang terdapat pada persamaan garis singgung lingkaran banyak dan rumus-rumus yang harus peserta didik pelajari sehingga peserta didik kesulitan untuk menyelesaikan permasalahan yang berkaitan dengan persamaan garis singgung lingkaran (Nurbaiti \& Arcana, 2019). Selain itu, penggunaan buku digital pada materi persamaan garis singgung lingkaran juga mengikuti perkembangan zaman, yang mana sekarang sudah memasuki era industri 4.0 yang semua pekerjaan menggunakan alat teknologi. Termasuk pembelajaran, maka dibuatlah pembelajaran dengan menggunakan buku digital.

Penelitian yang dilakukan oleh Putrawansyah (2016), diperoleh hasil bahwa digital book berbasis android valid, praktis, dan cukup efektif. Persamaan penelitian terletak pada pengembangan buku digital yang berbasiss android. Sedangkan perbedaannya adalah interaktif. Penelitian ini mengembangkan buku digital yang interaktif. Hasil dari penelitian ini adalah pembelajaran dengan menggunakan digital book berbasis android memiliki keefektifan terhadap hasil belajar peserta didik.

Penelitian yang dilakukan oleh Marselina \& Muhtadi (2019), hasil yang diperoleh adalah layak digunakan dan efektif. Persamaan penelitian terletak pada pengembangan buku digital yang interaktif. Perbedaannya adalah penyajian buku digital pada penelitian ini menampilkan penyelesaian dari soalsoal, jika subjek menjawab soal yang salah maka akan keluar penyelesaian. Sedangkan penelitian Marselina dan Muhtadi, tidak menampilkan penyelesaian hanya menampilkan jawaban yang benar dan jawaban yang salah saja. Hasil dari penelitian ini adalah buku digital yang diciptakan interaktif 
efektif untuk meningkatkan hasil belajar peserta didik.

Dari permasalahan yang telah dipaparkan, maka dilakukan sebuah penelitian pengembangan buku digital pada materi persamaan garis singgung lingkaran. Oleh karena itu, tujuan penelitian ini untuk mendeskripsikan pengembangan buku digital pada materi persamaan garis singgung lingkaran yang valid. Harapan dari penelitian ini adalah untuk menghasilkan produk buku digital interaktif yang valid dan efektif untuk meningkatkan hasil belajar peserta didik tentang persamaan garis singgung lingkaran.

\section{METODE PENELITIAN}

Penelitian ini adalah Research and Development (R\&D) atau penelitian pengembangan. Model penelitian ini menerapkan model ADDIE, tetapi pada penelitian ini hanya menerapkan tahap analysis, design, dan development (ADD). Hal ini dikarenakan, pelaksanaan implementasi memakan banyak waktu dan proses yang lama, serta uji coba yang harus sesuai dengan materi yang sedang berlangsung (Maimunah et al., 2019). Selain itu, juga dikarenakan proses pembelajaran juga dilakukan secara online karena masih pada masa pandemic Covid-19, sehingga penelitian ini sulit untuk dilakukan implementasi atau dilakukan secara langsung kepada peserta didik.

Untuk tercapainya pengembangan buku digital yang valid, harus melakukan beberapa tahap model ADD. Tahap analysis, terdiri dari analisis kurikulum, analisis materi/konsep, dan analisis tujuan pembelajaran. Tahap design, yaitu mulai merancang buku digital. Tahap development, dilakukan penilaian para ahli yaitu tiga ahli materi dan dua ahli media yang bertujuan untuk mengetahui kevalidan buku digital.

Data yang diperoleh pada penelitian ini adalah kualitatif dan kuantitatif. Metode pengumpulan data yang digunakan adalah angket. Instrumen penelitian yang digunakan adalah lembar validasi ahli materi dan ahli media, yang mana pedoman penskoran diadaptasi dari skala Likert terdiri dari 5 pilihan, yang bertujuan untuk mengetahui tingkat kualitas sebuah produk yang dikembangkan (Febrian \& Fera, 2019). Teknik analisis data yang digunakan adalah statistika deskriptif untuk menganalisis data kevalidan buku digital dari penilaian para ahli.

Analisis data yang diperoleh ditentukan dari rataan skor dengan bantuan msi. Tujuan msi adalah untuk mengubah data ordinal menjadi data interval. Kemudian, data interval tersebut diolah untuk mencari persentase rata-rata. Setelah didapat hasil persentase rata-rata, maka akan dicocokan dengan persentase yang ada pada tabel interval kategori kevalidan.

Interval persentase kevalidan yang dapat dilihat pada Tabel 1.

Tabel 1. Interval kategori kevalidan.

\begin{tabular}{cc}
\hline Interval & Kategori \\
\hline $75 \%-100 \%$ & Sangat Valid \\
$50 \%-75 \%$ & Valid \\
$25 \%-50 \%$ & Kurang Valid \\
$0 \%-25 \%$ & Tidak Valid \\
\hline \multicolumn{2}{c}{ Sumber: Kristanti \& Julia (2017) }
\end{tabular}

\section{HASIL DAN PEMBAHASAN}

Proses penelitian ini menggunakan model ADD, yaitu analysis, design, dan development. Hasil yang diperoleh adalah buku digital berbasissn android pada materi persamaan garis singgung lingkaran kelas XI SMA. 
Berikut adalah deskripsi tahapan pengembangan buku digital:

a) Tahap Analysis (Analisis)

Tahap analysis terdiri dari analisis kurikulum, materi/konsep, dan tujuan pembelajaran. Pada analisis kurikulum didapatkan hasil bahwa sekolah-sekolah terutama SMA sudah menggunakan kurikulum 2013 revisi 2018 yang menngacu pada Permendikbud Nomor 37 Tahun 2018 tentang KI dan KD kurikulum 2013. Penelitian ini difokuskan kepada mata pelajaran matematika peminatan kelas XI SMA semester genap. Selanjutnya, analisis materi/konsep dilakukan dengan cara mencari materi atau sumber belajar lainnya yang berkaitan dengan persamaan garis singgung lingkaran. Berdasarkan analisis konsep, maka dipilihlah materi persamaan garis singgung lingkaran untuk buki didital. Analisis tujuan pembelajaran diperoleh hasil IPK (indikator pencapaian kompetensi). IPK disusun berdasarkan analisis kurikulum dan analisis materi/konsep. Berikut ada tujuan pembelajaran persamaan garis singgung lingkaran, 1) Peserta didik mampu menyelesaikan persamaan garis singgung lingkaran melalui titik yang berpusat di titik $(0,0),(a, b)$, dan bentuk umum. 2) Peserta didik mampu menyelesaikan persamaan garis singgung lingkaran dengan gradien $m$. 3) Peserta didik mampu menyelesaikan persamaan garis singgung melalui titik di luar lingkaran

b) Tahap Design (Perancangan)

Tahap kedua adalah tahap perancangan. Pada tahan perancangan ini, peneliti mulai menyusun buku digital, dimulai pemilihan format BSNP 2014 dan menggunakan Adobe Flash Professional CS6 untuk pembuatan buku digital berbasiss android. Format BSNP 2014 terdiri dari cover, cover penyusun, kata pengantar, petunjuk penggunaan, tujuan pembelajaran, materi, latihan soal, glosarium, daftar pustaka, dan tentang penyusun.

c) Tahap Development (Pengembangan)

Pada tahap pengembangan, buku digital yang dikembangkan pada penelitian ini selesai. Tampilan dari cover penyusun buku digital dapat dilihat pada Gambar 1.

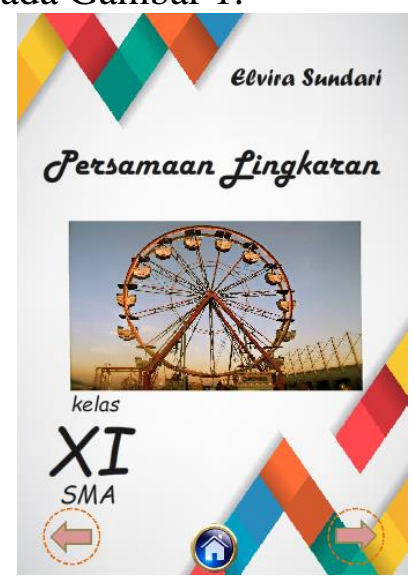

Gambar 1. Tampilan awal buku digital.

Selain tampilan awal, gambar dari tampilan materi persamaan garis singgung lingkaran dapat dilihat pada Gambar 2.

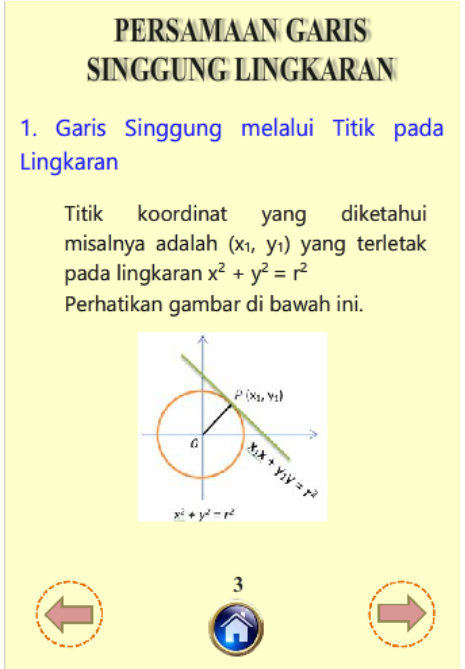

Gambar 2. Tampilan materi.

Pada buku digital terdapat latihan soal yang interaktif, jika peserta didik menjawab pertanyaan salah, maka akan tampak seperti Gambar 3. 
DOI: https://doi.org/10.24127/ajpm.v9i4.3084

\section{LATIHAN SOAL}

1. Persamaan garis singgung lingkaran $x^{2}+y^{2}=45$ yang melalui titik $(2,-3)$ adalah ...

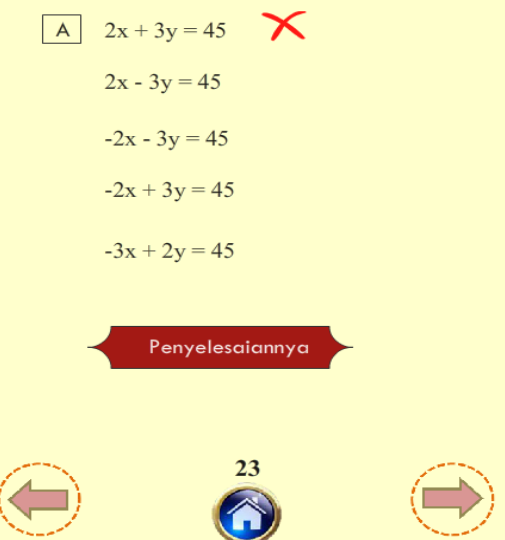

Gambar 3. Tampilan jika jawaban salah.

Selain pilihan jawaban yang salah, pasti ada juga peserta didik yang menjawab benar. Tampilan jika pertanyaan dijawab dengan benar dapat dilihat pada Gambar 4.

\section{LATIHAN SOAL}

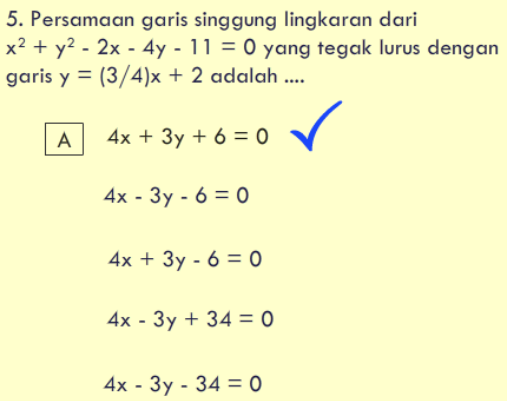

Gambar 4. Tampilan jika jawaban benar

Langkah selanjutnya adalah membuat lembar validasi ahli materi dan ahli media yang diadaptasi dari Dewi (2018). Buku digital kemudian dinilai oleh beberapa para ahli (expert review) yang terdiri dari tiga ahli materi dan dua ahli media. Berikut adalah hasil penilaian dari ahli materi dan hasil perbaikan buku digital.

Penilaian ahli materi 1 dominan pada pilihan setuju, dan dapat digunakan dengan revisi ringan.

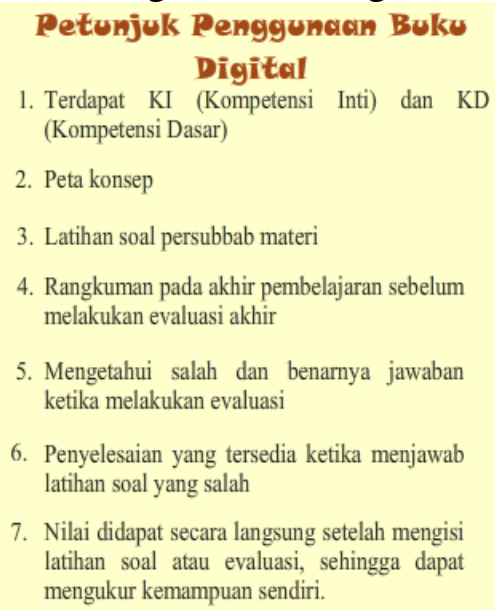

Gambar 5. Buku digital sebelum direvisi.

Menurut ahli materi 1, pada gambar 5, bukanlah sebuah petunjuk penggunaan buku digital. Maksud petunjuk disini adalah fungsi tomboltombol yang ada pada buku digital. Kemudian, diperbaiki petunjuk penggunaan dapat dilihat pada Gambar 6 .

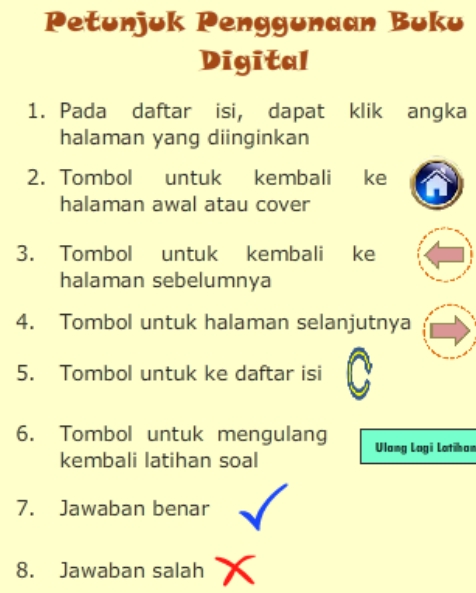

Gambar 6. Buku digital setelah direvisi

Penilaian dari ahli materi 2, dominan pilihan sangat setuju dan setuju, serta dapat digunakan dengan revisi ringan. 
DOI: https://doi.org/10.24127/ajpm.v9i4.3084

\section{PERSAMAAN GARIS SINGGUNG LINGKARAN}

Jawab:

Gradien yang didapat adalah -3.

$y-b=m(x-a) \pm r \quad V\left(m^{2}+1\right)$

$y+3=-3(x-2) \pm 8 \quad \sqrt{ }\left((-3)^{2}+1\right)$

$y+3=-3(x-2) \pm 8 \quad \sqrt{ }(9+1)$

$y+3=-3 x+6 \pm 8 \quad \sqrt{ } 10$

$y+3 x=-3+6 \pm 8 \quad \sqrt{ } 10$

$y+3 x=3 \pm 8 \quad \sqrt{ } 10$

Jadi, persamaan garis singgung adalah

$y+3 x=3+8 \quad \sqrt{ } 10$ dan $y+3 x=3-8 \quad \sqrt{ } 10$.

Gambar 7. Buku digital sebelum direvisi

Ahli materi 2, menyatakan bahwa gunakanlah kaidah matematika dengan benar, jangan seperti tanda ceklis saja. Sebelum direvisi seperti pada Gambar 7. Kemudian direvisi seperti pada Gambar 8.

\section{PERSAMAAN GARIS SINGGUNGLINGKARAN}

Jawab:

Gradien yang didapat adalah -3 .

$y-b=m(x-a) \pm r \sqrt{\left(m^{2}+1\right)}$

$y+3=-3(x-2) \pm 8 \sqrt{\left((-3)^{2}+1\right)}$

$y+3=-3(x-2) \pm 8 \sqrt{(9+1)}$

$y+3=-3 x+6 \pm 8 \sqrt{10}$

$y+3 x=-3+6 \pm 8 \sqrt{10}$

$y+3 x=3 \pm 8 \quad 10$

Jadi, persamaan garis singgung adalah

$y+3 x=3+8 \sqrt{10}$ dan $y+3 x=3-8 \sqrt{10}$.

Gambar 8. Buku digital setelah direvisi

Penilaian ahli materi 3 dominan pada pilihan setuju dan dapat digunakan dengan revisi ringan.

\section{PERSAMAAN GARIS SINGGUNGLINGKARAN}

Bacalah permasalahan di bawah ini dengan seksama!

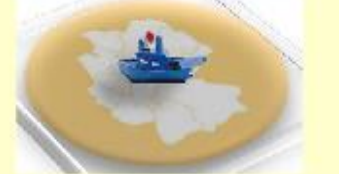

Suatu kapal ikan berada pada $(5,10)$ dengan memiliki radar $25 \mathrm{~km}$ kesegala arah. Dengan adanya radar tersebut, Pak Nelayan dapat mencari ikan dengan mudah. Suatu ketika, gerombolan sotong mendekati radar kapal ikan tersebut, tepat di sisi radar dengan koordinat $(7,14)$. Maka persamaan garis yang terbentuk dari gerombolan sotong tersebut adalah ....

Gambar 9. Buku digital sebelum direvisi

Ahli materi 3 hanya menambahkan sedikit kata-kata yang berkaitan dengan koordinat (Gambar 9). Dapat dilihat perbaikannya pada Gambar 10.

\section{PERSAMAAN GARIS SINGGUNGLINGKARAN}

Bacalah permasalahan di bawah ini dengan seksama!

Suatu kapal ikan yang ditempatkan pada koordinat $(5,10)$ dengan memiliki radar $25 \mathrm{~km}$ kesegala arah. Dengan adanya radar tersebut, Pak Nelayan dapat mencari ikan dengan mudah. Suatu ketika, gerombolan sotong mendekati radar kapal ikan tersebut, tepat di sisi radar dengan koordinat (7, 14). Maka persamaan garis yang terbentuk dari gerombolan sotong tersebut adalah ....

Gambar 10. Buku digital setelah direvisi

Berdasarkan Tabel 1 dan juga hasil analisis dari msi, penilaian buku digital berbasiss android pada materi persamaan garis singgung lingkaran dari ahli materi termasuk kategori valid dengan perolehan persentase $\mathbf{7 2 , 2 \%}$. Sesuai dengan penelitian yang 
dilakukan oleh Argarini, Yazidah, \& Kurniawati (2019), bahwa smart book yang dikembangkan diperoleh hasil valid dari aspek materi.

Penilaian dari ahli media 1 dan 2 tidak terlalu banyak, dominan pada pilihan sangat setuju dan setuju, serta dapat diujicobakan dengan revisi ringan.

Berdasarkan tabel interval kevalidan dan juga hasil analisis dari $m s i$, penilaian buku digital berbasis android pada materi persamaan garis singgung lingkaran dari ahli media termasuk kategori valid dengan perolehan persentase $\mathbf{5 4 , 2 5 \%}$. Sesuai dengan penelitian yang dilakukan oleh Jazuli (2017), bahwa bahan ajar elektronik yang dikembangkan diperoleh hasil valid dari aspek materi.

Dengan demikian, penilaian dari ahli materi dan ahli media dapat diambil rata-rata atau hasil penilaian ahli materi dan ahli media dijumlahkan kemudian dibagi dua, maka diperoleh persentase kevalidan 63,22\% yang dikategorikan valid. Sesuai dengan penelitian yang dilakukan oleh Putra \& Anggraini (2016) bahwa pengembangan bahan ajar berbasis software Imind map dinyatakan valid dari segi materi dan media.

Berdasarkan hasil penelitian yang ditemukan, bahwa buku digital yang dihasilkan interaktif, mudah digunakan, mudah diakses, mudah dipahami baik dari segi materi maupun segi bahasa, serta buku digital yang memiliki tampilan menarik. Selain kelebihan tersebut, ada juga kekurangannya yaitu buku digital yang berbasis android yang menggunakan alat elektronik sebagai alat bantunya, maka kemungkinan mengalami kehabisan baterai sehingga tidak bisa mengakses buku digital pada materi persamaan garis singgung lingkaran.

\section{KESIMPULAN DAN SARAN}

Penelitian ini menghasilkan sebuah produk, yaitu buku digital berbasiss android pada materi persamaan garis singgung lingkaran kelas XI SMA yang valid. Dengan penilaian dari para ahli (ahli materi dan ahli media) adalah $63,22 \%$ yang dikategorikan valid. Jadi, dapat disimpulkan bawah buku digital pada materi persamaan garis singgung lingkaran pada kelas XI SMA yang dikembangkan dinyatakan valid.

Saran untuk penelitian yang akan datang adalah buku digital persamaan garis singgung lingkaran yang valid dapat diujicobakan kepada sasaran pengguna yaitu peserta didik kelas XI SMA semester genap dengan tujuan untuk memperoleh kepraktisan dan keefektifan buku digital ini.

\section{DAFTAR PUSTAKA}

Argarini, D. F., Yazidah, N. I., \& Kurniawati, A. (2019). Pengembangan smart book materi geometri untuk siswa SMP berbasis konstruktivisme. AKSIOMA: Jurnal Program Studi Pendidikan Matematika, 8(2), 344-353.

https://doi.org/10.24127/ajpm.v8i2. 2156

Cholik, C. A. (2017). Pemanfaatan teknologi informasi dan komunikasi untuk meningkatkan pendidikan di Indonesi. Syntax Literate: Jurnal Ilmiah Indonesia, 2(6), 21-30.

Dewi, C. K. (2018). Pengembangan Alat Evaluasi Menggunakan Aplikasi Kahoot pada Pembelajaran Matematika Kelas X (Skripsi). Universitas Islam Negeri Raden Intan Lampung. 
Febrian, \& Fera, M. (2019). Kualitas perangkat dan keterampilan mengajar mahasiswa pendidikan matematika pada mata kuliah micro teaching menggunakan analisis model rasch. Jurnal Gantang, 4(1), 87-95. https://doi.org/10.31629/jg.v4i1.10 65

Jamun, Y. M. (2018). Dampak teknologi terhadap pendidikan. Jurnal Pendidikan Dan Kebudayaan Missio, 10(1), 48-52.

Jazuli, M. (2017). Pengembangan Bahan Ajar Elektronik Berbasis Android Sebagai Media Pembelajaran. Jurnal Lensa (Lentera Sains): Jurnal Pendidikan IPA, 7(20), 47-65.

Kristanti, D., \& Julia, S. (2017). Pengembangan perangkat pembelajaran matematika model 4D untuk kelas inklusi sebagai upaya meningkatkan minat belajar siswa. Jurnal Maju, 4(1), 38-50.

Maimunah, Izzati, N., \& Dwinata, A. (2019). Pengembangan lembar kerja peserta didik berbasis realistic mathematics education dengan konteks kemaritiman untuk peserta didik SMA kelas XI. Jurnal Gantang, 4(2), 133-142.

Marselina, V., \& Muhtadi, A. (2019). Pengembangan buku digital interaktif matematika pada materi geometri. Jurnal Inovasi Teknologi Pendidikan, 6(2), 196-207.

Nurbaiti, \& Arcana, I. N. (2019). Pengembangan youtube pembelajaran kedudukan garis terhadap lingkaran di SMA menggunakan videoscribe. UNION: Jurnal Pendidikan Matematika, 7(1), 229-239. https://doi.org/10.30738/union.v7i 1.4053
Prasetya, D. D., Widiyaningtyas, T., \& Prastuti, E. (2016). Buku digital cerita anak berbasis mobile. Tekno, 26(2), 130-135.

Putra, R. W. Y., \& Anggraini, R. (2016). Pengembangan bahan ajar materi trigonometri berbantuan software Imind map pada siswa SMA. Al-Jabar: Jurnal Pendidikan Matematika, 7(1), 39-47.

Putrawansyah, F. (2016). Pengembangan Digital Book Berbasis Android Materi Perpindahan Kalor di Sekolah Menengah Atas. Indonesian Journal on Networking and Security, 5(4), 39-48.

Putri, D. P. (2018). Pendidikan karakter pada anak sekolah dasar di era digital. Ar-Riayah: Jurnal Pendidikan Dasar, 2(1), 37-50.

Wirasasmita, R. H., \& Uska, M. Z. (2017). Pengembangan media pembelajaran berbasis buku digital elektronic publication (epub) menggunakan software sigil pada mata kuliah pemrograman dasar. EDUMATIC: Jurnal Pendidikan Informatika, 1(1), 11-16. https://doi.org/10.29408/edumatic. v1i1.732 